розпорядженням Кабінету Міністрів від 24.07.2013 № 1071 [Електронний ресурс]. Режим доступу: mpe.kmu.gov.ua/minugol/doccatalog/document?id $=260994$

5.Закон України «Про ратифікацію Протоколу про приєднання України до Договору про заснування Енергетичного Співтовариства» від 15.12.2010 № 2787-VI [Електронний ресурс]. - Режим доступу: http://zakon4.rada.gov.ua/laws/show/994_a27
6. Крістіне Розенбергер. Політика України в галузі енергетики. Представництво фонду Конрада Аденауера в Україні, 2012 [Електронний ресурс]. - Режим доступу: http://www.kas.de/ukraine

7. Кудлай В. С. Аналіз ефективності використання енергетичних ресурсів / В. С. Кудлай, Л. С. Селіверстова // Вісник Київського національного університету технологій та дизайну. - 2013. - № 6. - С. 49-64.

Рецензент д.е.н., професор НТУ «ХПІ» Кузьминчук Н.В. Експерт редакційної колехії к.е.н., доцент УкрДУЗТ Слагін Ю.В.

УДК: 330.101.541

\title{
КУМІВСЬКИЙ КАПТТАЛІЗМ ЯК ЯВИЩЕ СУЧАСНОЇ ЕКОНОМІКИ УКРАЇНИ
}

Тертичний О. О., к.т.н., доцент, Бородавка О.А., доцент (ХІФ УДУФМТ)

У статті розглянуто питання функиіонування та розвитку, наведено основні ознаки кумівського капіталізму в сучасній економічній системі України, визначено їх особливості. Головною діючою силою такого строю є клан. Клан - ие неформальні групи людей, пов'язаних родинними або іншими ознаками (регіональними, за освітою та ін), які обов'язково включають бізнесменів та державних службовиів, достатньо часто працівників правоохоронних органів та політиків, іноді представників організованої злочинності, та, особливість України, воєнізовані формування у вигляді охоронних агентстві та ін. Наведено рекомендаџї щуодо боротьби з иими явищами

Ключові слова: кумівський капіталізм, корупція, протидія кумівському капіталізму.

\section{КУМОВСКОЙ КАПИТАЛИЗМ КАК ЯВЛЕНИЕ СОВРЕМЕННОЙ ЭКОНОМИКИ УКРАИНЫ}

\author{
Тертичный А. О., к.т.н., доцент, \\ Бородавка О.А., доцент (ХИФ УГУФМТ)
}

В статье рассмотрены вопросы функиионирования и развития, приведены основные признаки кумовского капитализма в современной экономической системе Украины, определены их особенности. Главной действуюшей силой такого строя является клан. Клан - это неформальные группь людей, связанных родственными или другими признаками (региональными, по образованию и т.д.), которые обязательно включают бизнесменов и государственных служащих, достаточно часто работников правоохранительных органов и политиков, иногда представителей организованной преступности, и, особенность Украины, военизированные формирования в виде охранных агентстве и др. Приведены рекомендации по борьбе с этими явлениями.

Ключевые слова: кумовской капитализм, коррупция, противодействие кумовскому капитализму, борьба с коррупщией. 


\title{
CRONY CAPITALISM AS A PHENOMENON MODERN ECONOMY OF UKRAINE
}

\author{
Tertichny O.O., Candidate of Engineering Sciences, associate professor, \\ Borodavka O.A., associate professor (KhIF USFIT)
}

The questions of crony capitalism in the modern economic system of Ukraine, are defined by their features. The main structure of this system is the clan. Clan - a informal group of people related features (regional, education and so on) that are sure to include businessmen and government officials, often law enforcement officials and politicians are sometimes organized crime, and especially in Ukraine, paramilitaries as a security agency and others. The phenomenon of crony capitalism is negative and interferes with the normal development of the country. In order to effectively deal with it, you must become familiar with its causes and consequences. Unfortunately, today indigenous research in this direction does not exist. It is necessary to continue research in this direction. The situation in Ukraine requires a fundamental change in the patterns of interaction between political and economic institutions. In fact, only Ukraine needs people who are ready to sacrifice the benefits of dubious political career, people who are more important than long-term results than the short-term benefits, and the people who can share positive experiences and put their strength and energy to the development of the country. corruption.

Keywords: crony capitalism, corruption, opposition to crony capitalism, fight against

Постановка проблеми. Сучасний стан економіки України $є$ вкрай незадовільним. До цього привели декілька причин, в тому числі несформованість економіки країни, проблеми суспільного та політичного життя країни. Однією $з$ головних причин такого стану як економіки, так i суспільства в цілому, $\epsilon$ розвиток непотизму, який охопив усе суспільство.

Аналіз останніх досліджень $\boldsymbol{i}$ публікацій. Питання фаворитизму, непотизму та кронізму під час формування політикоуправлінської еліти у розробках сучасних вчених розкрито не повністю. Серед суттєвих розробок цієї сфери слід виділити роботи таких зарубіжних та вітчизняних науковців, як Б. Алпер Буйюкарслан[1], С. Вей [2], Дж.Ф.Девис[3], Д. Соломон[4], Н. Катрі [5, 6], М. Пірен[7], О. Томкіна[8], О.Олійник[9] та ін., але вони досліджують ці явища на прикладі своїх країн (наприклад Н.Катрі розглядає питання непотизму у Індіï) та не розглядають особливостей сучасної України. Тому це питання на сьогодні вивчено не у повному обсязі та потребує подальшого вивчення.

Виділення невирімених частин загальної проблеми.

В умовах нестабільної економічної $\mathrm{i}$ політичної ситуації в країні актуалізується проблема розвитку кумівського капіталізму. У ряді країн багатство у багатьох випадках стає синонімом високої політичної посади або означає, що його власник (рідше власниця) родич, друг чи прихильник (одним словом, «кум») когось із можновладців і його багатство пов'язане не з виробництвом корисних товарів, а 3 привілеями, які держава представляє одним людям на шкоду іншим. Як це не прикро, поняття «кумівський капіталізм» характеризує i економіку України - країну, де збанкрутілим фірмам все частіше «допомагають» за рахунок коштів платників податків. Основною діючою силою такої системи є поняття «клану», що широко застосовується в медіа, реальних ділових відносинах, при проведенні конкретних політичних розрахунків. Однак він практично не опрацьований в науковій літературі. Також немає і аналізу соціально-економічної системи, в якій клани займають центральне місце.

Mema cmammi - проаналізувати розвиток кумівського капіталізму в сучасній Україні, визначити його національні особливості та розробити методи протидії їх впливу на економіку та політичну систему країни.

Викладення основного матеріалу

Проаналізувавши роботи щодо розвитку цього явища $[2,4,5,8]$, можна надати наступне визначення.

Кумівський капіталізм - різновид капіталістичної економіки, у якому замість принципу особистої ефективності використовується принцип ефективності клану. На мезо- та макроекономічному рівні 
економічної системи починає діяти така структура, як клан. Будучи головними дійовими особами сформованої системи, вони являють собою неформальні групи людей, пов'язаних родинними або іншими ознаками (регіональними, за освітою та ін), які обов'язково включають бізнесменів та державних службовців, достатньо часто працівників правоохоронних органів та політиків, іноді представників організованої злочинності, та, особливість України, воєнізовані формування у вигляді охоронних агентстві та ін. У межах клану неформальні внутрішньогрупові норми і правила поведінки грають більш істотну роль, ніж формальні закони, i недотримання перших карається набагато більш серйозно, ніж порушення друге. Дуже небезпечною рисою такої системи $\epsilon$ можливість становлення особливої «кланової держави», основна функція якої полягає в забезпеченні сприятливих умов роботи найбілыших кланів, забезпечення розмежування ïx інтересів, створення переваг перед усіма іншими учасниками політичного та економічного життя. У цьому зв'язку мова звичайно йде про «корупцію», хабарі, «відкати» та інших порушеннях законів. Проте в Україні ці явища набули характеру системної риси, суть якої - створення умов для отримання різних ресурсів у розпорядження кланів та їх членів.

Ще однією неприємною рисою такого суспільства $є$ номенклатурне (бюрократичне) підприємництво, коли ролі чиновника i підприємця не відокремлені один від одного і часто їх одночасно виконують одні й ті ж люди. Мова йде не просто про заступництво 3 боку чиновників якимось фірмам, які особливо дороги їхньому серцю, як в деяких країнах Латинської Америки, Південно-Східної Азії або в інших частинах світу[5], де ці ролі більшменш чітко розподілені. У нашому випадку - це поява людей, які, 3 одного боку, регулюють і контролюють якусь сферу ділового життя як «державні люди», а з іншого - роблять в цій же сфері гроші як приватні бізнесмени.

Наступна риса кланового капіталізму монополізм, який носить переважно неринковий характер. Монополізм може виникати в будь капіталістичній системі як природний наслідок роботи ринкового механізму. Він насамперед пов'язаний з появою великих, ефективно працюючих фірм, які відвойовують значну частку ринку, перемагаючи своїх конкурентів за рахунок більш низької ціни, більш високої якості продукції і так далі. Негативні наслідки таких «ринкових успіхів» добре відомі, і так само добре відомо, як 3 ними боротися, застосовуючи антимонопольне законодавство. Але в ситуації кланового капіталізму, монополія в основному виникає не в результаті ринкових успіхів приватних фірм, а внаслідок діяльності самої держави, точніше, тих самих бізнесменів-чиновників. Переслідуючи власні ділові інтереси, ці «бізнесмени» можуть (і часто роблять в реальності) довільно передати державні замовлення «своїм» фірмам, зменшити число суб'єктів ринку силовими методами (перевірки контролюючих органів, порушення кримінальних справ, відмова у видачі ліцензіi) або видати розпорядження, зобов'язує держоргани сприяти «своїй» фірмі.

I, нарешті, найважливіша риса кланового капіталізму - інституціоналізація тіньової економіки, укорінення ii в ділових відносинах практично всіх суб'єктів, від дрібних сімейних фірм до органів влади всіх рівнів. За наявними оцінками, в країнах 3 перехідною економікою тіньова частина становить приблизно чверть валового продукту, в Україні вона досягає 40-50\%, тоді як у розвинених країнах, що входять в Організацію 3 економічного співробітництва та розвитку (ОЕСР), вона становить приблизно 15\%.

Для аналізу розповсюдження кумівського капіталізму звернемо увагу на індекс кумівства капіталізму. Журнал Economist [10] розрахував економічні показники 23 країн - п'яти найбільших розвинених, 10, що розвиваються i ще восьми країн, де, як вважається, кумівство переважає в бізнесі. Чим вище коефіцієнт, тим більша ймовірність, що економіка страждає від кланового капіталізму. При розрахунку індексу враховувалися галузі, вразливі до монополій або включають ліцензування, або участь держави. Саме в таких галузях, згідно 3 рейтингами Transparency International, визначають високий рівень корупції. Недолік такої системи визначення рівня кумівства полягає у тому, що у різних країнах перелік галузей за ступенем державного регулювання різний. Наприклад, реалізація продуктів домашніх господарств в Україні проводиться практично без дозволів, у Росії потребує довідки голови сільської ради, на території Євросоюзу взагалі заборонено. 
Модифікація індексу кумівства буде розглянута у наступних роботах.

3 великих економік світу найвищі (тобто гірші) показники кумівства виявилися у Росії. Під час перебудови політичні кола захопили природні ресурси, і російські олігархи стали ще багатшими, а ціни на сировинні товари зросли. Наступну позицію після Росії займає Малайзія, за ними йде Україна.

Вплив такої соціально-економічної системи приводить до наступного:

підприємці змушені витрачати час на діалог з нарочито прискіпливими чиновниками, навіть якщо вдається уникнути хабарів;

підтримуються неефективні проекти, фінансуються роздуті кошторису, вибираються неефективні підрядники;

корупція стимулюе створення надмірного числа інструкцій, щоб потім за додаткову плату «допомагати» їx дотримуватися;

3 державної служби йдуть кваліфіковані кадри, морально не приймає систему хабарів;

виникають перешкоди для реалізації макроекономічної політики держави, оскільки корумповані нижчі і середні ланки системи управління спотворюють передану уряду інформацію i підпорядковують реалізацію намічених цілей інтересам кланів;

корупція деформує структуру державних витрат, так як корумповані політики i чиновники схильні направляти державні ресурси в такі сфери діяльності, де неможливий строгий контроль i де вище можливість вимагати хабарі;

збільшуються витрати для підприємців (особливо для середнього бізнесу, найбільш беззахисного у цій ситуаціі); до керівництва

потрапляе

некваліфікований персонал; посилюється

несправедливість у вигляді нечесної конкуренції фірм i невиправданого перерозподілу доходів громадян. Адже дати більш великий хабар може неефективна фірма або навіть злочинна організація. В результаті зростають доходи хабародавців i хабароотримувачів при зниженні доходів інших громадян;

корупція в системі збору податків дозволяє багатим ухилятися від них $\mathrm{i}$ перекладає податковий тягар на плечі бідніших громадян; управлінський персонал психологічно не готовий поступатися своїми особистими інтересами заради розвитку суспільства;

корупція дискредитує правосуддя, оскільки правим виявляється той, у кого більше грошей та кращі зв'язки і менше самозаборон;

створюється загрозу демократії, оскільки позбавляє населення моральних стимулів до участі у виборах;

гасло боротьби 3 корупцією та кумівством може привести до диктатури i відмови від ринкових реформ;

корупція в апаратах, що відповідають за правозастосування (армія, поліція, суди), дозволяе організованої злочинності розширювати свою «грабіжницьку» діяльність в приватному секторі i навіть створювати симбіоз організованої злочинності i цих організацій;

такі режими ніколи не користуються «любов'ю» громадян, а тому вони політично нестійкі;

зменшується рівень конкуренції;

хабарі перетворюються на свого роду додаткове оподаткування;

виникають легальні види хабарів у вигляді консультацій, оцінювання та ін.

Наведемо декілька рис Українського кумівського капіталізму:

- численні розгалужені бюрократичні апарати - лихо українських держструктур. Як результат - негативні ефекти: знеособленість, ритуализм, інерція, які ускладнюють елементарні операції, але при цьому встановлюють традиції хабарництва та шляхи в обхід «для своїх»;

- Інститут тіньової економіки. Крадіжка грошей з бюджету, відкати і хабарі стають характерною рисою всіх організацій i компаній. Такий спосіб ведення справ закріплюється, неефективним стає відкрите ведення бізнесу. В умовах кумівського капіталізму підприємства, не залучені в тіньову економіку, мають набагато менше шансів на успіх, ніж ті, що підв'язані на корумповані структури.

Таким чином, економіка при «кумівському» капіталізмі - це багато в чому обмежений інститут, що базується на усталених ділових i особистісних стосунках між невеликою кількістю підприємців та чиновників. Це монополізований ринок, обтяжений безліччю високих податків, 
бюрократизованих процедур, правової незахищеності, заплутаних законодавчих актів. Він природно менш привабливий для нових проектів, інвесторів і зарубіжних партнерів, а тому не має можливостей будь-якого істотного зростання.

Що ж можна зробити для боротьби 3 цим явищем? Головною проблемою «кумівського» капіталізму $\epsilon$ те, що він являється системою, яка охоплює усе суспільство, і як на рівні держави, так і на місцевому рівні відсутнє бажання боротися 3 ним. Для покращення ситуації необхідно провести наступні заходи:

посилити прозорість процедур управління на різних рівнях, зробити ці процедури більш простими;

спростити законодавство, зробивши його прозорим та простим у використанні;

вести агітаційну та пояснювальну роботу, підвищуючи загальний моральний рівень суспільства;

покращувати добробут населення.

Висновки. Явище кумівського капіталізму $\epsilon$ негативним та заважає нормальному розвитку країни. Для того, щоб ефективно 3 ним боротися, необхідно добре вивчити його причини та наслідки. Нажаль, на сьогодні докорінних досліджень у цьому напрямку не існує. Необхідно продовжувати дослідження у цьому напрямку.

Чи має Україна умови досить сприятливі для того, щоб відбулися позитивні зміни в сфері економіки? Скоріше так, ніж ні. Ситуація в Україні не безнадійна, хоча i вимагає кардинальної зміни схем взаємодії між політичним і економічним інститутами. По суті, Україні потрібні тільки люди, готові пожертвувати сумнівними благами політичної кар'єри, люди, яким важливіше довгострокові результати, ніж короткострокова вигода, i люди, які можуть поділитися позитивним досвідом і вкласти свої сили та енергію в розвиток країни.

\section{СПИСОК ЛІТЕРАТУРИ}

1. Alper Buyukarslan B. The overall outlook of favoritism in organization: A literature review / B. Alper Buyukarslan, N. Derya Ergun Ozler // International Journal of Business and Management Studies. - 2011. - Vol. 3, № 1. - P. 275-284.

2. Wei, S.-J. (2001), Domestic Crony Capitalism and International Fickle Capital: Is There a Connection?. International Finance, 4: 1545. doi: 10.1111/1468-2362.00064

3. Davis, Gerald F. (2003). "American cronyism: How executive networks inflated the corporate bubble". Contexts 2 (3): 34-40. doi:10.1525/ctx.2003.2.3.34

4. Solomon D. Nepotism, patronage and the public trust / D. Solomon. - 27 February 2014 [Електронний ресурс]. - Режим доступу: http://www.integrity.qld.gov.au/library/document/ca talogue/speeches-articles/Nepotism\%20and $\% 20$ the $\%$-20public\%20trust $\% 20$ (2).pdf

5. Khatri, N., Tsang, E.W.K., \& Begley, T. 2006. Cronyism: A cross-cultural analysis. Journal of International Business Studies, 37(1): 61-75. [Also in T. G. Andrews and R. Mead (Eds.), Cross Cultural Management, Volume 2 -The Impact of Culture 1: 126-150. Routledge, UK.]

6. Khatri, N., Tsang, E.W.K., \& Begley, T. 2003. Cronyism: The downside of social networking. The Best Papers Proceedings of the Academy of Management, Seattle

7. Пірен М. I. Проблеми формування сучасної української еліти / М. І. Пірен // Соціальна психологія. - 2004. - № 2 (4). - С. 3848.

8. Томкіна О. Принцип доброчесності державної влади: постановка проблеми / O. Томкіна // Вісник Національної академії правових наук України. - 2014. - № 1 (76). - С. $65-74$.

9. Олійник О. Фаворитизм і кронізм як основні критерії кадрового добору політикоуправлінської еліти в Україні / О. Олійник // Віче. - 2014. - № 20. - С. 2-5. - Режим доступу: http://nbuv.gov.ua/j-pdf/viche_2014_20_2.pdf

10. The Economist. Our crony-capitalism index: Planet Plutocrat. The Economist (2014). [Електронний ресурс] - Режим доступу: http://www.economist.com/news/international/2159 9041-countries-where-politically-connectedbusinessmen -are-most-likely-prosper-planet

Рецензент д.е.н., заст..директора НДУ «УНДІЕП» Дмитрісва О.О. Експерт редакційної колегії к.е.н., дочент УкрДУЗТ Назаренко І.Л.

Вісник економіки транспорту і промисловості № 51, 2015 